\title{
THE EARLIEST TAXONOMIC DESCRIPTION AND ILLUSTRATION OF AN AUSTRALIAN REPTILE: ANOTHER HISTORICAL FIRST FOR BLUETONGUE LIZARDS (SQUAMATA: SCINCIDAE: TILIQUA)
}

\author{
by Glenn M. Shea
}

(with one plate)

\begin{abstract}
SHEA, G.M., 2000 (31:xii):The earliest taxonomic description and illustration of an Australian reptile: another historical first for bluetongue lizards (Squamata: Scincidae: Tiliqua). Pap. Proc. R. Soc. Tasm., 134: 79-82. ISSN 0080-4703. Department of Veterinary Anatomy and Pathology, University of Sydney, NSW, Australia 2006.
\end{abstract}

\begin{abstract}
Manuscript descriptions of several species of reptiles prepared in 1777 by William Anderson, naturalist on James Cook's third voyage of discovery, are reported and, where possible, identified. The most thorough description is of the Blotched Bluetongue, Tiliqua nigrolutea, based on a specimen collected from Adventure Bay, Bruny Island, and painted by the artist John Webber. This description, though not previously published, is the earliest known formal scientific description of an Australian reptile, and the painting is the earliest scientific illustration of an Australian reptile.
\end{abstract}

Key Words: history, Tasmania, systematics, Squamata, Scincidae, Tiliqua.

While no thorough formal historical study of Australian herpetology has yet been undertaken, Whitley (1970) and Tyler (1976) provide some details of the early history. Although there are a few earlier mentions, either explicit or (by naming of localities) implicit, of the occurrence of sea turtles and crocodiles in Australian waters, Dampier (1729), in an account widely reprinted (Flinders 1814 , Alexander 1914, Ride 1962, Serventy 1970, Whitley 1970 , Serventy \& Raymond 1974, Stanbury 1978, Stanbury \& Phipps 1980 , Stanbury 1987, Greer 1989), provides the earliest description of an Australian reptile that is identifiable to species. Dampier's account is evidently of a Shingleback (Tiliqua rugosa), seen at Shark Bay in 1699. Dampier's description, however, antedates the introduction of formal binomial nomenclature by Linnaeus, and only refers to the lizard as the New Holland Guano (a presumed corruption of iguana, also later corrupted to produce the Australian term goanna).

Just over 60 years after Dampier's account, the earliest published scientific descriptions of Australian reptiles appeared in White's (1790) Journal of a Voyage to New South Wales. Although there is some controversy over the authorship of the species names proposed (e.g. Sherborn 1891, Alexander 1924, Tyler \& Dobson 1973, Shea 1993), it is generally recognised that most of the descriptions of animals were the work of George Shaw and John Hunter. Five names were applied to Australian lizards, each of which was accompanied by a formal diagnosis and illustration, although an additional six snakes and one lizard were illustrated and briefly described without application of names. The first reptile description to appear (White 1790: 242) is Lacerta scincoides, now known as Tiliqua scincoides, the Eastern Bluetongue Skink.

Thus, bluetongue lizards were the earliest Australian reptiles described in print and the first Australian reptiles to receive a formal scientific name.

The account in White's Journal, however, is not the earliest formal scientific description and illustration of an Australian reptile. During James Cook's third, fatal voyage to the Pacific, between 1776 and 1780 in the ships Resolution and Discovery, he stopped at Adventure Bay, on Bruny Island off eastern Tasmania, in January 1777. While there, the naturalist on the voyage, the surgeon William Anderson, observed and described a large lizard. Anderson, like Cook, died during the voyage. When James Douglas prepared Cook's account for publication, he included numerous excerpts from Anderson's manuscript journal. Thus, Cook's Voyage ..., Vol.I (1784: 110) included Anderson's description of his lizard: "we killed a large, hitherto unknown, lizard, fifteen inches long and six round, elegantly clouded with black and yellow". This account was repeated by Eden (1787). Anderson's manuscript journal was finally published by Beaglehole (1967); here the same passage reads: "a large Lizard above fifteen inches long and six round, elegantly clouded with black and yellow was kill'd", with a footnote indicating the name "Lacerta tarda".

Both Beaglehole (1967) and Whitley (1970) identify Anderson's lizard as Tiliqua nigrolutea, the largest lizard in Tasmania and the only one to attain the size described. Whitley also noted (1970: 55) that Anderson's manuscript descriptions, in the British Museum (Natural History), now the Natural History Museum, London, contain Latin descriptions of the animals from Tasmania, and that the large lizard was painted by John Webber, one of the artists on the expedition (1970: 60). However, Whitley published neither description nor illustration.

Webber's painting of the lizard, now in the collection of the Department of Prints and Drawings at the British Musuem, is also mentioned by Beaglehole (1967: ccxiv), and again in a catalogue of the artwork of the expedition (Joppien \& Smith 1985), but it has only recently been published for the first time (Shea 1998). The illustration (pl. 1) is in pen and black ink with watercolour over graphite (C. Serhan, pers. comm.), and is unequivocally identifiable as Tiliqua nigrolutea.

Through the courtesy of Ms Ann Datta, I have been able to obtain a copy of Anderson's full manuscript description of this animal (Anderson 1776-78). The Latin description appears twice, the first time on p.8, the second time on p. 28, where it is accompanied by an English translation. The second Latin description (here published for the first time, with line breaks indicated) reads: 


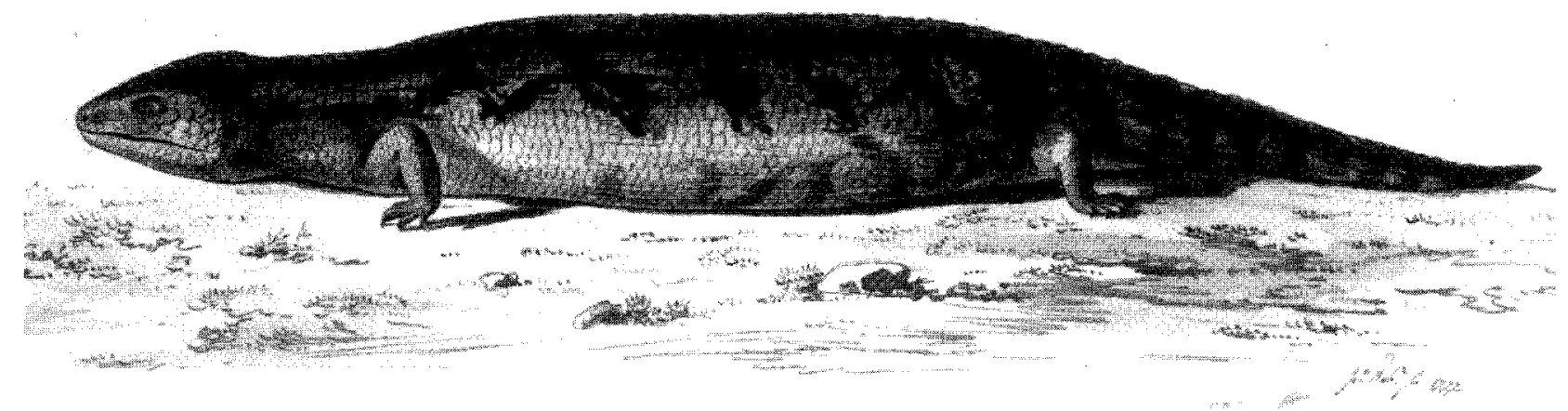

FIG. 1 - Monochrome reproduction of John Webber's painting of a blotched bluetongue (Tiliqua nigrolutea) from Adventure Bay, Bruny Island, Tasmania.

\section{Lacerta tarda}

Longitudo unciae quindecem, quorum [sic] Cauda tantum 5 est - /Circumferentia unciae sex.

Corpus depressum, imbricatum, squamis validis subrotundis. /Cauda teres, crassa, sensim versus apicem decrescens./Buccae subgibbosae, subflavae, auribus perspicuis. Pedes/pentadactyli, unguiculati. Vertex fuscus - Corpus supra /ex luteo nigroque oblique undulatum, s[eu] obscure decussat/um - Corpus subtus cinereus, sed cauda nigro variega/ta - Lingua lata, obtusa, livida, carnosa. /Habitat in terra Diemeni Ambulat tarde.

The English description, which mostly corresponds to the Latin version, reads:

12. Drawing Lacerta tarda: or slow Lizard.

The Length fifteen inches, of which the tail is only five. - /The Circumference - six inches./

The body flatted \& coverd with large roundish scales. /The tail round, thick \& gradually decreasing towards the point. /The cheeks somewhat gibbous \& yellowish, with very conspicu/ous Ears behind. - The feet have five toes furnish'd with claws. /The top of the head brown - The upper part of the body wav'd, /or rather obscurely cross'd obliquely, with black and yellow. I Underneath it is of an ash colour, but varied with black on /the tail - The tongue broad, blunt, thick or fleshy, \& livid - /It inhabits Van Diemens Land. /Fig. pict. Webber.

The first Latin description differs from the later version only in minor points. Apart from punctuation, the only differences are "quinque" for "5 est", "subconcavis" for "perspicuis", the omission of "Corpus" before "subtus cinereum", the change in order of "obtusa, livida, carnosa" to "carnosa, obtusa, livida", and the omission of reference to the illustration.

This description and illustration, although unpublished until recently, appear to be the first formal description and European illustration of an Australian reptile. This is also among the earliest post-Linnaean names applied to any reptile species. Further, Anderson was the first to report the blue tongue which now gives the genus its common name, bluetongue lizard, a name which first appeared in the published literature over a century later (Anon 1885).
The description of Lacerta tarda, though brief by modern standards, is not only quite acceptable by the standards of the day but positively loquacious. Anderson used as his herpetological reference Linnaeus' Systema Naturae (Keevil 1933), in which most lizards were placed in a single genus, Lacerta, accompanied by brief diagnoses of a few lines. Although Laurent (1768) had initiated the dismemberment of this genus, his changes were not adopted by English scientists for many years. The later lizard descriptions in White's (1790) Journal are likewise all referred to Lacerta.

Anderson's description refers to colouration, body size and shape, number of digits and claws, all treated as major diagnostic features in contemporary lizard descriptions and sufficient to differentiate the species from the 48 Lacerta species listed by Linnaeus (Linné 1766).

Webber's illustration, likewise, concentrates on body proportions and, to a lesser extent, colour pattern. The lack of attention to the configuration of head scales is typical of other illustrations of the period. The importance of scale configuration, size and number in differentiating lizard species was not appreciated until the following century.

The fate of Anderson's specimen remains unknown, if, indeed, it was retained by him to send home. Keevil (1933) suggested that some of the collections remained in Russia, as security for supplies received, while Whitehead (1969) and Medway (1979) document the tortuous routes followed by the material that returned to Sir Joseph Banks in London. Of the extant museums thought to have received material from Cook's voyages, there are no identifiable Anderson or Banks specimens of Tiliqua nigrolutea in Leningrad (Strauch 1866), Vienna (Fitzinger 1826), Berlin (Lichtenstein 1823; pers. obs.) or in the Natural History Museum, London (Boulenger 1887).

Anderson's journal and zoological manuscript also mentioned other reptiles, although no new names were provided for these. Cook (1784) ascribed to Anderson mention of several large blackish snakes at Adventure Bay (presumably copperheads, Austrelaps superbus, known from Bruny Island - Green \& Rainbird 1993), although Anderson's journal (Beaglehole 1967) gave no indication of colour. [Note added in proof - One of the referees of this paper reported tiger snakes, Notechis scutatus, from Bruny Island. This species is also a possible contender for the large black snakes sighted by Anderson.] Anderson's manuscript descriptions listed two other lizards, in a separate appendix "Animalia genere dubio s[eu] imperfecte visa 
continens". The first of these, also from Adventure Bay, and also mentioned in his journal ("a small sort, of a brown gilded colour above, and rusty below" - Cook 1784, Beaglehole 1967) was identified as similar to Linneaus' Lacerta punctata:

3. Lacerta affinis punctata/Corpus laeve subrotundrum. Cauda corpore longior teres. /Pedes pentadactyli unguiculati - Dorsum ex aureo-fuscum, /linea flava punctis nigris, interne terminatum - Lateres /nigri, linea albida infra. - Gula grisea, nigro punctata - $\mathrm{Ab}$ / domen ferrugineum -. /Habitat in terra Diemeni

This lizard is probably either Niveoscincus metallicum or $N$. pretiosum, both known from most nearby islands, although not formally reported yet from Bruny Island (Green \& Rainbird 1993), neither species was formally named until almost a century later (O'Shaughnessy 1874).

The second lizard, from Otakoo Island, a locality I am unable to identify, is identified as similar to Linnaeus' Lacerta gecko:

5 Lacerta affinis Gecko? /L: Magnitudo dimidio Geckonis.? Corpus subluteum, /cauda mediocri, ore magna, auribus concavis, oculis gri/seis, iride lanceolata perpendiculare, pedibus unguicu/latis, digitisque subtus membranaeus.- / Habitat in insula Otakoo, taia.Scandit arbores-.

It is possible that Otakoo Island is in Queen Charlotte's Sound, New Zealand, as Cook (1784) reported two to three sorts of lizards from this area.

\section{ACKNOWLEDGEMENTS}

I thank Ms Ann Datta of the Zoology Library, Natural History Museum, London for providing me with a copy of Anderson's descriptions, and the Dept of Prints and Drawings, British Museum, for permission to reproduce Webber's illustration. Dr P. Shea translated Webber's Latin descriptions, while A. Bauer provided information on Linnaeus' publications.

\section{REFERENCES}

AleXander, W.B., 1914: The history of zoology in Western Australia. Part I. - Discoveries in the 17 th century. J. Nat. Hist. Sci. Soc. WA 5: 49-64.

Alexander, W.B., 1924: White's Journal of a Voyage to New South Wales. Emu 23: 209-215.

ANDERSON, W., 1776-78: Unpublished manuscript: Zoologia nova seu Characteres \& Historia Animalium hacterus incognitorum qui in itinire nostro videbantur. 1776 in Linguis Latinis \& Anglicis traditus. Zoology Library, Natural History Museum, London.

Anon., 1885: Field Naturalists' Club of Victoria. Annual Conversazione. Vic. Nat. 2: 2-16

BEAGLEHOLE, J.C. (Ed.), 1967: THE JOURNALS OF CAPTAIN JAMES COOK ON HIS VOYAGES OF DISCOVERY. VOL. III. THE VOYAGE OF THE RESOLUTIONAND DISCOVERY 1776-1780. PART TWO. Cambridge University Press \& Hakluyt Society, Cambridge.

BOULENGER, G.A., 1887: CATALOGUE OF THE LIZARDS IN THE BRITISH MUSEUM (NATURAL HISTORY). VOL. III. Lacertidae, Gerrhosauridae, Scincidae, Anelytropidae, Dibamidae, Chamaeleontidae. Trustees of the British Museum, London.
COOK, J., 1784: A VOYAGE TO THE PACIFIC OCEAN. UNDERTAKEN, BY THE COMMAND OF HIS MAIESTY, FOR MAKING DISCOVERIES IN THE NORTHERN HEMISPHERE. TO DETERMINE THE POSITION AND EXTENT OF THE WEST SIDE OF NORTH AMERICA; ITS DISTANCE FROM ASIA; AND THE PRACTICABILITY OF A NORTHERN PASSAGE TO EUROPE. PERFORMED UNDER THE DIRECTION OF CAPTAINS COOK, CLERKE, AND GORE, IN HIS MAIESTY'S SHIPS THE RESOLUTION AND DISCOVERY. IN THE YEARS 1776, 1777, 1778, 1779, AND 1780. VOL. I. G. Nicol \& T. Cadell, London.

DAMPIER, W., 1729: A VOYAGE TO NEW HOLLAND, \& C. IN THE YEAR 1699. J. \& J. Knapton, London.

EDEN, W., 1787: THE HISTORY OF NEW HOLLAND, FROM ITS FIRST DISCOVERY IN 1616, TO THE PRESENT TIME. WITH A PARTICULAR ACCOUNT OF ITS PRODUCE AND INHABITANTS; AND A DESCRIPTION OF BOTANY BAY: ALSO, A LIST OF THE NAVAL, MARINE, MILLITARY, AND CIVIL ESTABLISHMENT. TO WHICH IS PREFIXED, AN INTRODUCTORY DISCOURSE ON BANISHMENT. 2nd edn. John Stockdale, London.

FITZINGER, L.I., 1826: NEUE CLASSIFICATION DER REPTILIEN NACH IHREN NATÜRLICHEN VERWANDTSCHAFTEN. NEBST EINER VERWANDTSCHAFTSTAFEL UND EINEM VERZEICHNISSE DER REPTILIEN-SAMMLUNG DES K.K. ZOOLOGISCHEN MUSEUM'S ZU WIEN. J.G. Heubner, Wien.

FLINDERS, M., 1814: A VOYAGE TO TERRA AUSTRALIS; UNDERTAKEN FOR THE PURPOSE OF COMPLETING THE DISCOVERY OF THAT VAST COUNTRY, AND PROSECUTED IN THE YEARS 1801, 1802, AND 1803, IN HIS MAJESTY'S SHIP THE INVESTIGATOR, AND SUBSEQUENTLY IN THE ARMED VESSEL PORPOISE AND CUMBERLAND SCHOONER. WITH AN ACCOUNT OF THE SHIPWRECK OF THE PORPOISE, ARRIVAL OF THE CUMBERLAND AT MAURITIUS, AND IMPRISONMENT OF THE COMMANDER DURING SIX YEARS AND A HALF IN THAT ISLAND. VOL. I. G. and W. Nicol, London.

Green, R.H. \& Rainbird, J.L., 1993: Reptiles from the islands of Tasmania. Q. Vict. Mus. Art Gall. Tech. Rep. 1993/1 (not paginated).

GreEr, A.E., 1989: THE BIOLOGY AND EVOLUTION OF AUSTRALIAN LIZARDS. Surrey Beatty \& Sons, Chipping Norton

JOPPIEN, R. \& SMITH, B., 1985: THE ART OF CAPTAINCOOK'S VOYAGES VOL. 3. THE VOYAGE OF THE RESOLUTION AND DISCOVERY 1776-1780 WITH A DESCRIPTIVE CATALOGUE OF ALL KNOWN ORIGINAL DRAWINGS AND PAINTINGS OF PEOPLES, PLACES, ARTEFACTS AND EVENTS AND ORIGINAL ENGRAVINGS ASSOCIATED WITH THE VOYAGE. Oxford University Press, Melbourne.

Keevil, J.J., 1933: William Anderson, 1748-1778 Master Surgeon, Royal Navy. Ann. Med. Hist. (n.s.) 5: 51 1-524.

LAURENT, J.N., 1768: SPECIMEN MEDICUM, EXHIBENS SYNOPSIN REPTILIUM EMENDATUM CUM EXPERIMENTIS CIRCA VENENA ET ANTIDOTA REPTILIUM AUSTRIACORUM, QUOD AUTHORITATE ET CONSENSU ILLUSTRISSIMORUM, PERILLASTRIUM, MAGNIFICORUM, SPECTABILIUM, CLARISSIMORUM VRRORUM; ... Joan. Thomae, Vienna.

LICHTENSTEIN, H., 1823: VERZEICHNISS DER DOUBLETTEN DES ZOOLOGISCHEN MUSEUMS DER KÖNIGL. UNIVERSITÄT ZUBERLIN NEBST BESCHREIBUNG VIELER BISHER UNBEKANNTER ARTEN VON SÄUGETHIEREN, VOGELN, AMPHIBIEN UND FISCHEN. T. Trautwein, Berlin. 
LINNE, C. VON, 1766: SYSTEMA NATURAE PER REGNA TRIA NATURAE, SECUNDEM CLASSES, ORDINES, GENERA, SPECIES, CUM CHARACTERIBUS, DIFFERENTIIS, SYNONYMIS, LOCIS ... VOL. 1. PART 1. 12th edn. L. Salvii, Holmiae.

MEDWAY, D.G., 1979: Some ornithological results of Cook's third voyage. J. Soc. Bibliogr. Nat. Hist. 9: 315-351.

O'Shaughnessy, A.W.E., 1874: A description of a new species of Scincidae in the collection of the British Museum. Ann. Mag. Nat. Hist. (4) 13: 298-301.

RIDE, W.D.L., 1962: Narrative. In Fraser, A.J. (Ed.): THE RESULTS OF AN EXPEDITION TO BERNIER AND DORRE ISLANDS, SHARK BAY, WESTERN AUSTRALIA IN JULY, 1959. Western Australian Fisheries Department Fauna Bulletin (2).

SERVENTY, V., 1970: DRYANDRA. THE STORY OF AN AUSTRALIAN FOREST. A.H. \& A.W. Reed, Sydney.

Serventy, V. \& Raymond, R., 1974: The Shingleback Lizard. Aust. Wildl. Heritage 3: 1244-1248.

SHEA, G.M., 1993: The anatomist John Hunter (1728-1793), the Eastern Bluetongue Skink Tiliqua scincoides (Squamata: Scincidae) and the discovery of herbivory in skinks. Arch. Nat. Hist. 20: 303-306.

SHEA, G.M., 1998: Backyard blue-tongues. Nat. Aust. 26(3): 3039.

Sherborn, C.D., 1891: Note on the authors of the specific names in John White's 'Journal of a Voyage to New South Wales,' 1790. Ann. Mag. Nat. Hist. (6)7: 535.
Stanbury, P.J., 1978: AUSTRALIA'S ANIMALS WHO DISCOVERED THEM? Macleay Museum, Sydney.

Stanbury, P.J., 1987: The discovery of the Australian fauna and the establishment of collections. In Dyne, G.R. \& Walton, D.W. (Eds): FAUNA OF AUSTRALIA. VOL. IA GENERAL ARTICLES. Australian Government Publishing Service, Canberra.

Stanbury, P.J. \& Phipps, G., 1980: AUSTRALIA'S ANIMALS DISCOVERED. Pergamon Press, Sydney.

Strauch, A., 1866: Über die Arten der Eidechsengattung Cyclodus Wagl. Bull. Acad. Imp. Sci., St-Pétersbourg 10: 449-462.

Tyler, M.J., 1976: FROGS. William Collins (Australia), Sydney.

Tyler, M.J. \& Dobson, J., 1973: On the identity, authorship and fate of the type specimens of Rana caerulea. Herpetologica 29: 373-375.

WHITE, J., 1790: JOURNAL OF A VOYAGE TO NEW SOUTH WALES WITH SIXTY-FIVE PLATES OF NON DESCRIPT ANIMALS, BIRDS, LIZARDS, SERPENTS, CURIOUS CONES OF TREES AND OTHER NATURAL PRODUCTIONS. J. Debrett, Picadilly.

WhiteheAD, P.J.P., 1969: Zoological specimens from Captain Cook's voyages. J. Soc. Bibliog. Nat. Hist. 5: 161-201.

WHITLEY, G.P., 1970: EARLY HISTORY OF AUSTRALIAN ZOOLOGY. Royal Zoological Society of New South Wales, Sydney.

(accepted 17 July 2000) 